\title{
HAK ATAS KEKAYAAN INTELEKTUAL DALAM PERSPEKTIF ISLAM
}

\author{
Angga Carya Nashara \\ $185100039 P$ \\ Fakultas Komputer, 785567974 \\ anggacaryanashara.student@umitra.ac.id
}

\begin{abstract}
Abstrak
Manusia diciptakan Allah untuk menjadi khalifah di muka bumi. Dua tugas pokok yang diemban manusia sebagai khalifah, yaitu beribadah kepada Allah, dan membangun peradaban dimuka bumi. Untuk membangun peradaban dimuka bumi, Allah memberikan piranti yaitu kemampuan akal atau intelektual manusia untuk berkarya memakmurkan bumi melalui daya cipta, rasa, dan karsanya. Cipta, rasa dan karsa sebagai refleksi intlektual manusia dalam konteks dunia ekonomi merupakan asset yang sangat berharga dibanding dengan asset kebendaan lain.

Berdasar perspektif diatas, dalam tulisan ini penulis mengkaji permasalahan karya intlektual manusia, terutama mengenai hak kekayaan yang melekat pada karya intlektual, kedudukan dan dasar hukumnya dilihat dari sudut pandang fiqh muamalah. Hasil pembahasan ditemukan bahwa Karya Intlektual Manusia dilihat dari sudut fiqh termasuk kedalam hak ibtikar yang dipandang sebagai harta. Kedudukan bagi penemu atau penciptanya sebagaimana kedudukan kepemilikan benda-benda lainya, yaitu dapat diwariskan, diwasiatkan dan dipindahtangankan atau ditransaksikan.Dasar hukum Hak atas Kekayaan Intlektual Manusia adalah Urf dan Maslahah Mursalah. Hak atas Kekayaan Intlektual Manusia merupakan asset yang bernilai ekonomi Oleh sebab itu untuk menjaga eksistensi keberadaannya, harus mendapatkan perlindungan hukum dari pihak pemerintah baik lewat Undang-Undang atau Peraturan lain. Tindakan pemerintah mengatur hak atas kekayaan intlektual manusia ini tidak bertentangan dengan kaidah hukum Islam : “ Tasharuf (tindakan) Imam terhadap rakyat harus dihubungkan dengan kemaslahatan".
\end{abstract}

Kata Kunci : Kekayaan Intelektual Manusia, Hak Ibtikar, Hukum Islam 
A. Pendahuluan

Manusia diciptakan Allah untuk menjadi khalifah di muka bumi. Ada dua tugas pokok yang diemban menusia sebagai khalifah, yaitu disamping untuk beribadah kepada Allah, juga dituntut untuk membangun peradaban dimuka bumi. Untuk dapat membangun perdaban dimuka bumi, Allah memberi sarana atau piranti yaitu kemampuan akal atau intelektual manusia untuk berkarya memakmurkan bumi, baik dibidang ilmu pengetahuan, seni sastra, social, ekonomi, dan teknologi melalui daya cipta, rasa, dan karsanya. Karya-karya intelektual yang dilahirkan dengan penuh pengorbanan tersebut menjadikan karya yang bernilai ekonomi. Nilai ekonomi ini sangat berbeda dengan nilai ekonomi yang muncul bukan dari karya intelektual manusia, seperti kekayaan yang diperoleh dari alam, tanah atau tumbuh-tumbuhan berikut hak-hak kebendaan lain yang dihasilkan. Nilai ekonomi yang melekat dari karya intelektual manusia dalam konteks dunia dagang atau usaha merupakan aset perusahaan yang sangat berharga dibanding dari asset kebendaan

lain.

Perkembangan karya intelektual manusia pada akhirnya menimbulkan kebutuhan untuk melindungi atau mempertahankan kekayaan tersebut, yang yang pada akhirnya memerlukan adanya sikap penghargaan, penghormatan dan perlindungan yang tidak saja akan memberikan rasa aman, tetapi juga akan mewujudkan iklim yang kondusif bagi peningkatan semangat untuk menghasilkan karya-karya yang lebih besar. Melalui gambaran singkat diatas, tampak betapa kebutuhan akan pertumbuhan dan pengembangan system Hak kekayaan Intelektual manusia, yang sebenarnya berakar pada pada kebutuhan masyarakat itu sendiri yang merupakan bagian dari kebutuhan masyarakat akan perlindungan hukum dari pihak Negara atau pemerintah. Adanya perlindungan hukum seperti ini, dimaksudkan agar pemilik hak dapat menggunakan atau mengekploitasi kekayaan tadi dengan aman, yang pada akhirnya rasa aman itulah yang kemudian menciptakan suasana yang memungkinkan orang lain berkarya guna menghasilkan atau temuan berikutnya dan masyarakat dapat ikut menikmati dan menggunakannya atas dasar izin atau bahkan mengembangkannya secara lebih lanjut. Hal ini, berarti bahwa kehadiran system peraturan hukum merupakan syarat mutlak bagi berlangsungnya kegiatan ekonomi atau bisnis. Berdasarkan perspektif diatas, dalam tulisan ini, penulis merasa perlu mengkaji persoalan Hak atas Kekayaan Intelektual (HaKI) dari sudut pandang Hukum Islam. Permasalahan yang muncul untuk dicari jawabannya adalah : (1) apakah Hak atas Kekayaan Intelektual manusia (HaKI) termasuk kategori harta, dan bagaimana kedudukannya serta dasar hukumnya. bila dilihat dari segi Hukum Islam (Fiqh Muamalah). (2) Bagaimana pandangan Hukum Islam terhadap perlindungan hukum bagiHaKI. 
B.

B.HakIbtikar

Ibtikar secara bahasa berarti awal sesuatu atau permulaan. Ibtikar dalam fiqh Islam adalah hak kreasi atau hak cipta yang dihasilkan seseorang untuk pertama kali, yang dalam dunia ilmu pengetahuan Ibtikar dikenal dengan hak cipta.

Pengertian Ibtikar tidak ditemukan dalam literature fiqh klasik, kajian tentang Ibtikar secara mendalam dari para ahli hukum Islam juga jarang ditemukan. Pembahasan hak Ibtikar dapat dilacak dalam kitab fiqh kontemporer. Fathi ad-Duraini, menyatakan bahwa Ibtikar adalah gambaran pemikiran yang dihasilkan seorang ilmuwan melalui kemampuan pemikiran dan analisisnya dan hasilnya merupakan penemuan atau kreasi pertama, yang belum dikemukakan ilmuwan sebelumnya. Difinisi tersebut mengandung pengertian bahwa dari segi bentuk, hasil pemikiran itu tidak terletak pada materi yang berdiri sendiri yang dapat diraba dengan alat indra manusia, tetapi pemikiran itu baru berbentuk dan punya pengaruh apabila telah dituangkan kedalam tulisan, media atau logo dan lain-lain. Kemudian hasil pemikiran itu bukan jiplakan atau saduran atau pengulangan dari pemikiran ilmuan sebelumnya dan byukan pula berbentuk saduran. Akan tetapi ibtikar ini bukan berarti sesuatu yang baru sama sekali, tetapi boleh berbentuk suatu penemuan sebagai perpanjangan dari teori ilmuan sebelumnya seperti penerjemahan hasil pemikiran orang lain kedalam bahasa asing.. Penerjemahan dapat dimaukkan kedalam kategori ibtikar karena adanya usaha dan kemampuan bahasa penerjemah untuk menyebarluaskan suatu karya ilmiyah, meskip[un pemikiran aslinya bukan muncul dari penerjemah.

\section{SifatIbtikar}

Ibtikar hanyalah sebagai gambaran pemikiran dan gambaran pemikiran ini akan berpengaruh luas apabila telah dipaparkan atau dituangkan dalam bentuk tulisan atau cetakan maupun dalam media-media lainnya. Buah pikiran ilmuan sebagai ibtikar sebenarnya sebuah gambaran pemikiran yang belum berwujud materi. Akan tetapi pabila pemikiran ini telah dituangkan dalam bentuk media apapun, maka buah pemikiran itu akan berpengaruh luas baik dari segi material maupun pemikiran. Oleh karena itu, menurut ulama fiqh, ibtikar apabila dilihat dari sisi materinya, lebih serupa dengan manfaat suatu benda atau materi, seperti buah-buahan dan susu hewan perahan, apabila telah dipetik dari pohonya atau perahan dari hewan itu, karena pemikiran seseorang setelah dipisahkan dari pemikirnya dan dipaparkan pada suatu media, seminar atau simposiaum dan sebagainya, maka menjadi bersifat materi. Ulama fiqh lain membedakan antara hasil pemikiran seseorang dengan hasil atau manfaat suatu benda dari dua sisi : Pertama, dari sisi jenisnya, manfaat suatu benda, baik bergerak atau tidak bergerak, seperti manfaat rumah, lahan, 
buah-han, kendaraan dan hewan, berasal dari sumber yang bersifat material, yaitu rumah, lahan, [pepohonan, kendaraan itu senidiri dan hewan. Sedangkan sumber dari pemikiran sebagai suatu ciptaan atau kreasi seseorang bersumber dari akal seseorang manusia yang hidup dan mengerahkan kemampuan berpikirnya. Oleh sebab itu, dalam ibtiikar, sumber materinya tidak kelihatan. Kedua, dari segi pengaruhnya, manfaat dari bendabenda material merupakan tujuan utama dari suatu benda dan manfaat inilah yang dijadikan tolok ukur dari suatu benda. Akan tetapi, pengaruh dari sauatu pemikiran lebih besar disbanding manfaat suatu benda, karena pemikiran yang dituangkan dalam sevbuah buku atau media lain akan membawa pengaruh besar terhadap kehidupan manusia dan menunjukkan jalan bagi manusia untuk menggali sumber daya alam untuk menunjang kehidupan manusia itu. Hasil pemikiran inilah yang membedakan antara seseorang dengan lainnya, sehingga dalam al-Qur'an disebutkan bahwa apakah sama antara orang yang mengetahui dengan orang yang tidak mengetahui. (Q.S. azZumar, 39 9). Ibtikar atau hak cipta merupakan sesuatu hal yang baru dalam kajian hukum Islam, seiring dengan kemajuan dunia keilmuan, dunia usaha (dagang), dan kehidupan social budaya masyarakat. Ibtikar secara maknawi sebagai kepemilikan khusus, dan merupakan hasil karya intelektual manusia yang sudah selayaknya ada penghargaan khusus dari masyarakat umum baik dari segi moral maupun financial.

D.Kedudukan Hak Ibtikar dan dasar hukumnya. Ibtikar bila dikaitkan dengan pengertian harta dalam hukum Islam, menjadi perbedaan pendapat dikalangan ulama ahli fiqh. Menurut Ulama Hanafiyah, yang dinamakan harta adalah segala sesuatu yang mungkin disimpan dan bisa dimanfaatkan secara wajar. Pengertian ini membawa akibat bahwa sesuatu itu dapat dipandang harta, jika memenuhi dua unsure, yaitu (1) dapat disimpan, maka sesuatu yang tidak bisa disimpan tidak dipandang sebagai harta. (2) dapat dimanfaatkan secara biasa.Konsekwensi logis dari pendapat Ulama hanafiyah adalah yang dinamakan harta harus bersifat benda atau sesuatu yang bersifat materi atau yang bisa diindra (kasat mata). Sedangkan manfaat atau hak bukan dipandang sebagai harta, tetapi merupakan kepemilikan. Jumhur Ulama berpendapat bahwa harta adalah segala sesuatu yang mempunyai nilai dan orang yang merusakannya harus menggantinya atau menaggung beban atas kerusakannya. Imam Syafi'i mengatakan, almal(harta) dikhususkan pada sesuatu yang bernilai dan bisa diperjualbelikan dan memiliki konsekwensi bagi yang merusakkannya. Berdasarkan pengertian ini al-mal (harta) haruslah sesuatu yang dapat merefleksikan nilai finasial, dalam arti bisa diukur dengan satuan moneter. Konsekwensi logis dari pemikiran Jumhur Ulama ini adalah bahwa yang dinamakan harta tidak harus bersifat benda atau materi, tetapi bisa juga manfaat atau hak dapat dipandang sebagai harta. Alasan yang digunakan oleh Jumhur bahwa maksud 
orang memiliki suatu benda bukan karena semata-mata bendanya tetapi adalah manfaat dari benda itu sendiri. Pendapat Jumhur Ulama bila dikaitkan dengan hak Ibtikar, maka hasil pemikiran, ciptaan, dan kreasi seseorang termasuk harta, karena menurut mereka, harta tidak hanya bersifat materi, tetapi juga bersifat manfaat. Atas dasar ini, maka pemikiran, hak cipta, atau kreasi yang sumbernya adalah pemikiran manusia bernilai harta dan kedudukan sama dengan benda-benda lain, seperti mobil, rumah, dan sebagainya. Imam al-Qarafi berpendapat lain bahwa sekalipun hak ibtikar itu merupakan hak bagi pemikirnya, tetapi hak ini tidak bersifar harta, bahkan tidak terkait sama sekali dengan harta. Oleh sebab itu, menurutnya, hak ibtikar tidak boleh diwariskan, tidak boleh diwasiatkan dan tidak boleh ditransaksikan dengan transaksi yang bersifat pemindahan hak milik, Alsanya adalah karena yang menjadi sumber hak adalah akal dan hasil akal yang berbentuk pemikiran tidak bersifat material yang boleh diwariskan, diwasiatkan dan ditransaksikan. Krete5ria umum dalam harta yang dapat diwariskan, diwasiatkan atau dtransaksikan itu adalah bebrentuk harta atau yang bernilai harta. Sedangkan hak pada hasil pemikiran seseorang merupakan hak yang tidak bernmilai harta, karena sumbernya bukan harta, yaitu akal manusia. Pendapat al-Qarafi ini ditentang oleh ulama mayoritas ahli fiqh, anatar lain dari ulama Malikiyyah, yang menyatakan bahwa sekalipun asalnya adalah akal manusia, namun hak ibtikar setelah dituangkan dalam bentu media memiliki nilai harta yang besar, bahkan melebihi nilai sebagian harta benda material lain. Menurutnya, semata-semata pemikiran yang asalnya adalah akal seseorang tidak boleh dipindahktangankan. Akan tetapi setelah pemikiran itu dituangkan dalam bentuk media atu yang lain, maka hasil pemikiran itu telah bersifat material dan bernilai harta. Atas dasar ini, menurut ulama malikiyah hasil pemikiran itu dapat dipandang sebagai harta, apabila hasil pemikiran itu sudah dituangkan dalam bentuk tulisan, cetakan atau media apapun. Hak cipta atau kreasi karya intelektual manusia, merupakan hal baru dan belum ditemukan nash hukumnya (dalil khusus) baik dari ayat al-Qur'an maupun al-Hadits. Secara Ijtihadi dapat didasarkan pada : (1) "urf (suatu kebiasaan atau dapat yang berlaku umum dalam suatu masyarakat). Adat yang telah berjalan dan berlaku umum dapat dijadikan dasar hukum, sebagaimana dalam kaidah hukum Islam : " Adat Kebiasaan itu dapat ditetapkan sebagai hukum “. (2) Maslahah Mursalah adalah sesuatu yang dianggap maslahat, namun tidak ada ketegasan hukum untuk merealisasikannya dan tidak pula ada dalil tertentu baik yang mendukung maupun yang menolaknya, tetapi maslahah itu secara subtansial sejalan atau tidak bertentangan dengan petunjuk umum syari'at atau ruh syari'ah maupun maqasid syari'ah. Konsekwensi hukum Islam memandang bahwa hak Ibtikar termasuk kedalamn kategori harta yang berakibat bagi penemu atau pencipta terhadap hasil karya atau ciptaannya menjadi hak milik mutlak yang bersifat materi. 
Penemu atau pencipta berhak atas nilai materi itu atau hak tersebut, ketika digunakan atau dimanfaatkan oleh orang lain dengan seizinnya. Hak ini layaknya harta dan berlaku pada hukum yang melingkupinya. Berpijak dari hal tersebut, hak Ibtikar mempunyai kedudukan yang sama dengan kepemilikan harta lain yang bisa ditransaksikan, diwariskan atau diwasiatkan, maka untuk menjaga eksistensi keberadaan hak ibtikar tersebut dari hal-hal yang merusakkannya harus mendapatkan perlindungan hukum dari pemerintah lewat peraturan atau undang-ungdang dengan mempertimbangkan kemaslahatan kedua belah pihak. Tindakan pemerintah mengatur hak ibtikar bagi warga negaranya tidak bertentangan dengan kaidah hukum Islam : " Tasharuf (tindakan) Imam terhadap rakyatnya harus dihubungkan dengan ". Perlindungan hukum atas hak ibtikar seseorang lewat undang-undang atau hukum yang berlaku di Negara, dapat menghindari terjadinya penipuan dan kerugian dari pihakpihak yang saling bertransaksi dalam bisnis (perdagangan). Upaya pemerintah membuat aturan perlindungan hukum atas hak ibtikar bagi warga negaranya, disamping didasrkan pada "urf (adat) maupun maslahah mursalah, juga disemangati oleh hadits Nabi Saw : “ Rasulullah Saw pernah lewat seseorang yang sedang menjual bahan makanan, lalu Rasulullah memasukkan tangannya ke dalam bahan m akanan itu, lalu ternyata bahan makanan tersebut tipuaan. Maka rasulullah bersabda : tidak termasuk golongan kami orang yang menipu ". Berangkat daris hadits tersebut, dapat dibangun sebuah teori hukum Islam, bahwa keabsahan dan pembatalan suatu akad muamalat dalam bentuk apapun, ditentukan oleh tujuan akad yang menjadi "causa". Causa adalah maksud atau motif para pihak ketika melakukan transaksi, dengan causa ini merupakan sumber atau dasar kekuatan yang mengikat bagi tindakan hukum bersangkutan, yaitu dasar perlindungan hukum terhadap para pihak yang melakukan akad. Unsur penipuan dalam transaksi menandakan ada indicator "cacat kehendak" dari pelaku akad, yang memberikan kepada pihak yang dirugikan (tertipu) untuk membatalkannya.

E. Analisa Hukum Islam Terhadap Hak atas Kekayaan Intlektual Hak atas Kekayaan Intlektual manusia yang meliputi hak cipta, penemuan atau ciri khas usaha dagang, logo, merek dagang, system operasional bisnis terpadu dan sebagainya, bila dilihat dari sudut Hukum Islam, merupakan persoalan baru dalam kajian fiqh klasik. Persoalan yang muncul terkait dengan hak atas kekayaan intlektual, menyangkut status kepemilikan bagi pemiliknya dan hukum yang melingkupinya dalam pandangan hukum muamalat

Islam.

Hak atas kekayaan intlektual, dalam hukum Islam termasuk kategori hak Ibtikar, yaitu penemuan atau kreasi yang merupakan hasil karya intlektual manusia yang belum pernah ditemukan oleh ilmuwan sebelumnya. Hak atas kekayaan intlektual (HaKI) bila dihubungkan dengan pengertian harta dalam 
hukum Islam (dalam hal ini mengacu dengan teori Ulama Jumhur ), maka HaKi dapat dipandang sebagai harta, karena menurut Jumhur Ulama, yang dinamakan harta tidak harus bersifat materi atau benda, tetapi juga manfaat atau hak dapat dipandang sebagai harta. Alasannya bahwa maksud orang memiliki suatu benda bukan karena semata-mata bendanya tetapi adalah manfaat dari benda itu senidiri. Atas dasar ini, maka hak- atas kekayaan intlektual yang sumbernya adalah pemikiran manusia bernilai harta dan kedudukannya sama dengan kepemilikan benda-benda lain, yang berakibat bagi penemu atau pencipta terhadap karya atau ciptaanya menjadi hak milik mutlak yang bersifat materi sebagaimana dengan benda-benda lain yang dapat ditransaksikan, siwariskan atau diwasiatkan. Oleh sebab itu untuk menjaga eksistensi keberdaannya dari hal-hal yang meruisaknya, harus mendapatkan perlindungan hukum dari pihak Negara atau pemerintah baik lewat Undang-Undang atau peraturan lain. Tindakan pemerintah mengatur hak atas kekayaan intlektual manusia ini tidak bertentangan dengan kaidah hukum Islam : " Tasharuf (tindakan) Imam terhadap rakyat harus dihubungkan dengan kemaslahatan”. Adanya perlindungan hukum ini, disamping lebih memberikan kepastian hukum, juga dapat menghindari terjadinya penipuan dan kerugian dari pihak-pihak yang saling bertransaksi dalam

bisnis

Pemikiran Jumhur Ulama dipandang lebih relevan dengan perkembangan zaman, terutama kemajuan dibidang ekonomi. Karya-karya intlektual yang dilahirkan dengan pengorbanan menjadikan karya yang dihadirkan menjadi bernilai, apalagi dilihat dari manfaat ekonomi yang dapat dinikmati bagi dunia bisnis merupakan asset dagang atau persusahaan yang sangat berarti. Teori hukum Islam tentang hak Ibtikar sebagaimana yang dijelaskan dimuka, sesuai dengan ijtihad ahli-ahli ekonomi di Indonesia lewat Dewan Perwakilan Rakyat dengan memproduk Undang-Undang Hak atas kekayaan Intlektual (HaKI) yang meliputi Undang-Undang Nomor 19 Tahun 2002 tentang Hak Cipta, Undang-Undang Nomor 15 Tahun 2001 tentang Merek, UndangUndang Nomor 14 Tahun 2001 tentang Paten, dan Undang-Undang Nomor 30 tahun 2000 tenatang Rahasia Dagang. Dalam Undang-Undang HaKI tersebut pada asasnya memberikan hak penuh bagi penemu atau pemegangnya untuk mengalihkan haknya kepada siapa saja, baik untuk memanfaatkannya atau menggunajkannya atas seizinnya Hak atas kekayaan intlektual manusia, walaupun tidak ada landasan khusus atau dalil baik dari al-Qur'an maupun al-Hadits, secara ijtihadiyah dapat didasarkan pada "Urf" (suatu kebiasaan atau adapt yang berlaku umum dalam suatu masyarakat). Adat yang telah berjalan dan berlaku umum dapat dijadikan dasar hukum, sebagaimana dalam kaidah hukum Islam : " Adat Kebiasaan itu dapat ditetapkan sebagai hukum " dan "Maslahah Mursalah". yaitu sesuatu yang dianggap maslahat, namun tidak ada ketegasan hukum untukmerealisasikannya dan tidak pula ada dalil tertentu baik yang mendukung maupun yang menolaknya, tetapi maslahah itu secara subtansial sejalan atau tidak bertentangan dengan petunjuk umum syari'at atau ruh 
syari'ah

maupun

maqasid

syari'ah.

F.

Kesimpulan

Sebagai akhir tulisan ini, dapat diambil kesimpulan sebagai berikut : 1. Karya Intlektual Manusia dilihat dari sudut hukum Islam termasuk kategori hak ibtikar yang dipandang sebagai Harta. Kedudukan bagi penemu atau penciptanya sebagaimana kedudukan kepemilikan benda-benda lainya, yaitu dapat diwariskan, diwasiatkan, dipindahtangankan atau ditransaksikan. Dasar hukum Hak atas Kekayaan Intlektual manuia adalah Urf dan Maslahah Mursalah

2. Hak atas Kekayaan Intlektual Manusia merupakan asset yang bernilai ekonomi Oleh sebab itu untuk menjaga eksistensi keberadaannya dari hal-hal yang merusaknya, harus mendapatkan perlindungan hukum dari pihak Negara atau pemerintah baik lewat Undang-Undang atau poeraturan lain. Tindakan pemerintah mengatur hak atas kekayaan intlektual manusia ini tidak bertentangan dengan kaidah hukum Islam : " Tasharuf (tindakan) Imam terhadap rakyat harus dihubungkan dengan kemaslahatan". 
Daftar

Pustaka

Abd. Rahman, Asjmuni, 1976, Qaidah-Qaidah Fiqhiyyah, Jakarta ; Bulan Bintang, Satria.

Asy'ari. Musa, 1998, Islam dan Peradaban, Yogyakarta; Pustaka Pelajar Djuwaini,Dimyauddin i, 2008, Pengantar Fiqh Muamalah, Yogyakarta ; Pustaka

Effendi, Satria, 2002, Ushul Fiqh, Jakarta : Prenada Media, hal.148-149 Haroen, Nasrun, 1996, Ushul Fiqh I, Jakarta ; Logos Ibnu Majah, tt., Sunan Ibnu Majah, Beirut : Darul Fikr, Juz II, hal. 24 Margono, Suyud dan Amir Angkasa,2002, Komersialisasi Aset Intelektual Aspek Hukum Bisnis, Jakarta; Grasindo

Shobron, Sudarno, (Ed), 2003, Studi Islam 3, Surakarta; LSI-UMS.

Undang-Undang Nomor 19 Tahun 2002 Tentang Hak Cipta, Undang-Undang Nomor 15 Tahun 2001 Tentang Merek Undang-Undang Nomor 14 Tahun 2001 Tentang Paten Undang-Undang Nomor 30 Tahun 2000 tenatang Rahasia Dagang al-Zuhaili, Wahbah, 1997, al-Fiqh al-Islam wa Adillatuhu, Beirut : Dar alFikr, Juz IV, 